\title{
Optic neuritis complicating herpes zoster ophthalmicus in an immunocompetent patient Zoster optic neuritis in immunocompentent
}

Clovis Arcoverde Freitas-Neto $1,2,4$, Olga Cerón ${ }^{1,2}$, Katia Delalibera Pacheco ${ }^{3}$, Viviane Oliveira Pereira ${ }^{3}$, Marcos Pereira Ávila ${ }^{3}$ C. Stephen Foster ${ }^{1,2,5}$

\begin{abstract}
A 58-year-old woman presented with rash over the left side of the face and intense acute uveitis. Following careful review of the symptoms and dilated fundus examination unilateral optic neuritis was discovered. The rash was typical of varicella zoster dermatitis. Patients presenting with herpes zoster ophthalmicus should always undergo dilated fundus examination, as there is a potential risk of unexpected posterior segment inflammation. Early diagnosis and prompt treatment can avoid visual sequelae.
\end{abstract}

Keywords: Herpes Zoster Ophthalmicus/complications; Carrier State; Uveitis; Fundus oculi; Optic neuritis; Case reports

\section{ResUMO}

Paciente de 58 anos de idade apresentando erupção cutânea no lado esquerdo da face e intensa uveíte unilateral. Após cuidadosa revisão dos sintomas e exame de fundo do olho foi detectada neurite óptica. O rash era típico de dermatite por varicella zoster. Pacientes apresentando quadro de herpes zoster oftálmico devem ser submetidos ao exame de fundo do olho devido ao risco de inesperada inflamação do segmento posterior. Diagnóstico precoce e tratamento imediato podem evitar danos visuais.

Descritores: Herpes Zoster Oftálmico/complicações; Portador sadio; Uveítes; Fundo de olho; Neurite óptica; Relatos de casos

\footnotetext{
${ }^{1}$ Massachusetts Eye Research and Surgery Institution - Cambridge, MA, USA;

${ }^{2}$ Ocular Immunology and Uveitis Foundation - Cambridge, MA, USA;

${ }^{3}$ Centro Brasileiro da Visão - Brasília (DF), Brazil;

${ }^{4}$ Hospital de Olhos Santa Luzia - Recife (PE), Brazil;

${ }^{5}$ Harvard Medical School - Cambridge, MA, USA.
}

The authors declare no conflicts of interest

Recebido para publicação em 3/7/2014 - Aceito para publicação em 11/7/2014 


\section{INTRODUCTION}

$\mathbf{V}$ aricella zoster virus (VZV) can remain latent in sensory ganglia and can reactivate unpredictably producing inflammation. The neuronal damagge sometimes persists with debilitating pain as post herpetic neuralgia ${ }^{(1)}$. The virus produces a typical vesicular rash affecting one or more cutaneous dermatomes. Reduction of cellular immunity is one cause of VZV reactivation, humoral immunity persists intact in most cases ${ }^{(2)}$.

An epidemiologic study from the United States of VZV infection revealed an incidence of 3.2 per 1000 person-years according to diagnosis codes of health care claims. Rates were highest among individuals over 80 and with evidence of recent care for transplantation, HIV infection or cancer. Approximately half of the patients with $\mathrm{HZO}$ present with keratitis, conjunctivitis, or uveitis ${ }^{(3)}$.

Optic neuritis is one rare complication of herpes zoster ophthalmicus (HZO). This must be treated aggressively, because the visual prognosis is usually poor ${ }^{(4)}$. Here in, we describe a rare case in which the patient experienced rash, anterior uveitis associated with optic neuritis with clinical and visual improvement following aggressive treatment.

\section{Case report}

A 58 year-old woman presented to the emergency room complaining of a two-day history of pain and decreased vision in her left eye. At examination facial erythematous vesicles over the left ophthalmic branch of the trigeminal nerve were seen. The patient's best-corrected visual acuity was 20/20 in the right eye and 20/200 in the left eye. Slit lamp examination of the right eye was normal, her left eye revealed keratic precipitates, $3+/ 4+$ cells and $2+/ 4+$ flare in the anterior chamber (figure 1). Trace vitreous cells were noted in the left eye as well. Intraocular pressures by applanation tonometry were 12 and $34 \mathrm{mmHg}$, right and left eye respectively.

Fundus examination revealed left optic nerve swelling. Fluorescein angiography (FA) showed hyperfluorescence with late dye leakage in the left optic nerve and normal retinal circulation. Ocular coherence tomography (OCT) confirmed nerve inflammation revealing thickening of retinal fiber layers around the optic nerve head (figure 2$)^{(4,7)}$. The right eye was normal.

Treatment was started using cycloplegic and topical corticosteroid. Dorzolamide hydrochloride and timolol maleate were also instilled twice daily to reduce intraocular pressure. Prednisone $1 \mathrm{mg} / \mathrm{Kg}$ /daily and valacyclovir $1 \mathrm{~g}$ three-times-daily were prescribed. In 7 days the patient recovered her vision to 20/ 20 in both eyes. Intraocular pressure returned to normal limits. Oral prednisone was weaned weekly and after 4 weeks the patient presented with no signs of neuritis on FA and OCT. The optic nerve returned to physiologic anatomy without dye leakage and the retinal fibers layers returned to normal (figure 3).

\section{DisCUSSION}

Prior to an ophthalmological examination, a detailed history in patients with uveitis is essential. Some authors have stated that over $90 \%$ of diagnoses may be made on history grounds alone ${ }^{(5)}$.Varicella zoster virus has the potential to cause intraocular inflammation including iris atrophy, posterior synechia, secondary glaucoma, cataract and retinal necrosis ${ }^{(6)}$.

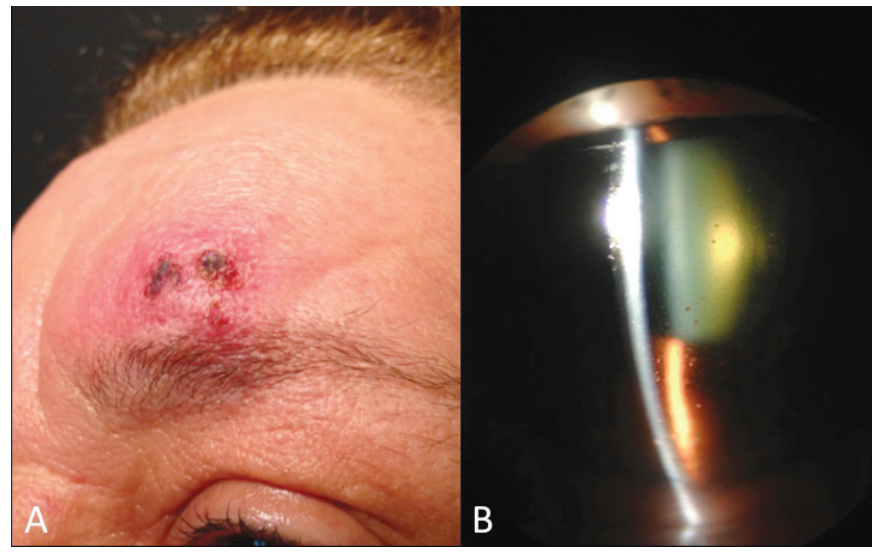

Figure 1: A - Rash over the left side of her forehead; B - Slit lamp examination: anterior uveitis with keratic precipitates and fibrin deposits overlying corneal endothelium

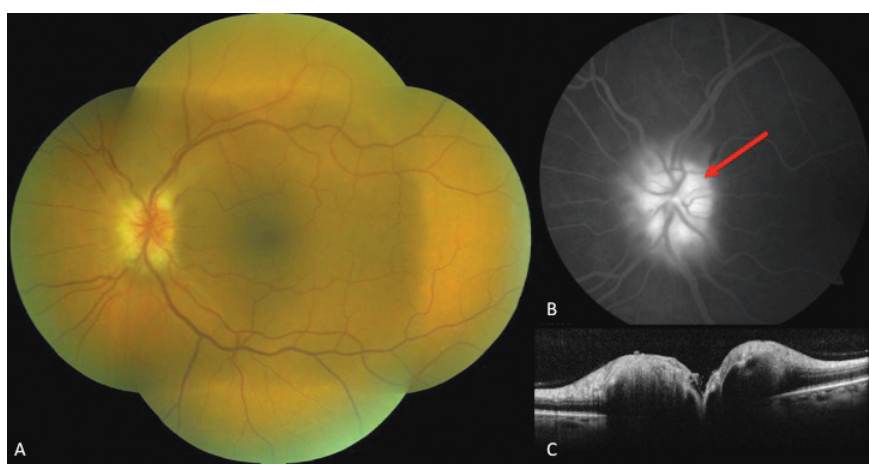

Figure 2: A - Hyperemic left optic nerve retinography; B - Late phase angiogram showing optic nerve leakage (red arrow); C Spectralis OCT: swelling of the right optic nerve

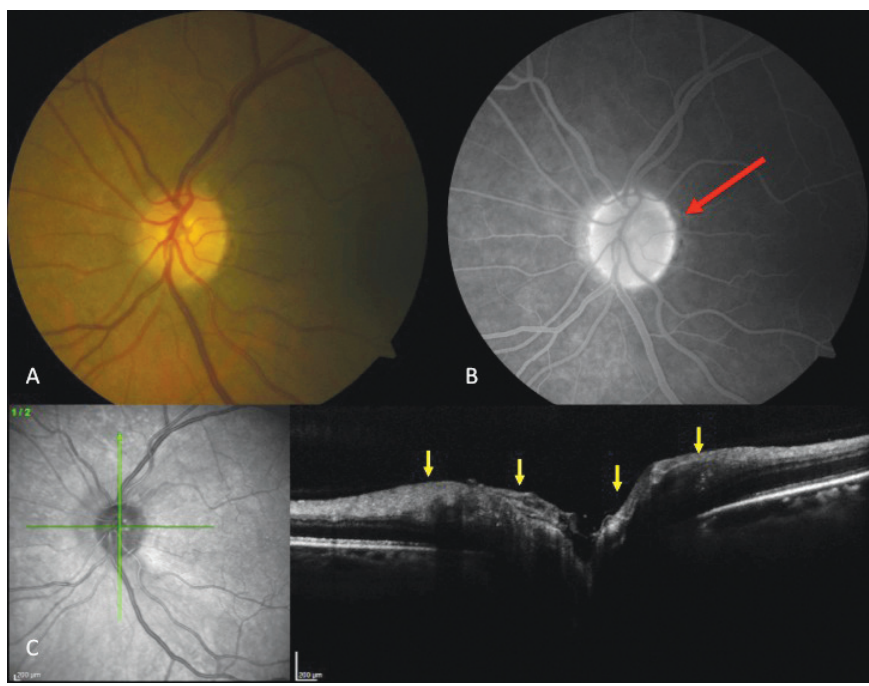

Figure 3: A - Normal left eye retinography; B - Late phase angiography without leakage or staining; $\mathrm{C}-$ Spectralis OCT: decrease of the retinal thickness around the optic nerve (yellow arrows)

Optic neuritis is a rare but possible complication of VZV infection ${ }^{(4,7)}$. Careful reviews of the symptoms are useful to the detection of HZO as well as having it as part of the differential diagnosis. In the described case, the diagnosis was based on the 
presence of vesicular rash, acute anterior uveitis and ocular hypertension. A positive serology for VZV supported the diagnosis.

The precise mechanism underlying optic neuropathy in $\mathrm{HZO}$ is unknown. Optic nerve inflammation may result from direct viral nerve infection through the cavernous sinus ${ }^{(5)}$. Oral antiviral drugs should be promptly administered to all patients with HZO, irrespective of age or severity of symptoms. As soon as our patient presented at the emergency room with rash and uveitis, antiviral drug and topical corticosteroids was prescribed. Valacyclovir was the antiviral medication of choice and was prescribed three-times-daily. Patients must be advised on the importance of a full course of therapy ${ }^{(8)}$.

Acyclovir has been the drug of choice in the therapy of herpes zoster infection for decades ${ }^{(9)}$. A other study with a large patient population demonstrated that valacyclovir offers significant advantages over acyclovir for the treatment of herpes zoster in immunocompetent adults ${ }^{(10)}$. Oral corticosteroids are also recommended in cases of optic neuropathy of HZO, simultaneous with antiviral treatment ${ }^{(8)}$. Our patient was treated for 4 weeks with combination therapy: oral valacyclovir and steroids leading to remission of ocular inflammation and recovery vision.

In conclusion optic neuritis is a rare complication of $\mathrm{HZO}$ in immunocompetent people and should be considered even in the setting of $\mathrm{HZO}$ with keratisis and/or anterior uveitis. Patients presenting with $\mathrm{HZO}$ should always undergo dilated fundus examination, as there is a potential risk of unexpected posterior segment inflammation. Early diagnosis and prompt treatment can avoid visual sequelae.

\section{REFERENCES}

1. Gilden DH, Kleinschmidt-DeMasters BK, LaGuardia JJ, Mahalingam $\mathrm{R}$, Cohrs RJ. Neurologic complications of the reactivation of varicellazoster virus. N Engl J Med. 2000;342(9):635-45.
2. WellerTH.Varicella and herpes zoster: changing concepts of the natural history, control, and importance of a not-so-benign virus. N Engl J Med. 1983;309(22):1362-8.

3. Insinga RP, Itzler RF, Pellissier JM, Saddier P, Nikas AA. The incidence of herpes zoster in a United States administrative database. J Gen Intern Med. 2005;20(8):748-53.

4. Wang AG, Liu JH, Hsu WM, Lee AF, Yen MY. Optic neuritis in herpes zoster ophthalmicus. Jpn J Ophthalmol. 2000;44(5):550-4.

5. Castro VM, Sakamoto FS, Orefice F. Uveítes virais. In: Oréfice F, Freitas-Neto, editores. Uveítes. 3a ed. Rio de Janeiro: GuanabaraKoogan; 2013. p.257-68. (Série Oftalmológica Brasileira, Conselho Brasileiro de Oftalmologia).

6. Capella MJ, Foster CS. Herpesvirus. In: Foster CS, Vitale AT, editor. Diagnosis and treatment of uveitis. 2nd ed. New Delhi: Jaypee Brothers Medical Publishers; 2013. p. 437-60.

7. de Mello Vitor B, Foureaux EC, Porto FB. Herpes zoster optic neuritis. Int Ophthalmol. 2011;31(3):233-6.

8. Gupta N, Sachdev R, Sinha R, Titiyal JS, Tandon R. Herpes zoster ophthalmicus: disease spectrum in young adults. Middle East Afr J Ophthalmol. 2011;18(2):178-82.

9. Whitley RJ, Gnann JW. Acyclovir: a decade later. N Engl J Med. 1992;327(11):782-9.

10. Beutner KR, Friedman DJ, Forszpaniak C, Andersen PL, Wood MJ. Valaciclovir compared with acyclovir for improved therapy for herpes zoster in immunocompetent adults. Antimicrob Agents Chemother. 1995;39(7):1546-53.

\section{Corresponding author}

Clovis Arcoverde Freitas Neto

Massachusetts Eye Research and Surgery

Institution

5 Cambridge Center, 8th Floor

Cambridge - MA - 02142

Telephone: (617) 621-6377

E-mail: cfreitas@hospitalsantaluzia.com.br 